\title{
Lethal Mycobacterium Bovis Bacillus Calmette Guérin Infection in Nitric Oxide Synthase 2-Deficient Mice: Cell-Mediated Immunity Requires Nitric Oxide Synthase 2
}

\author{
Irene Garcia, Reto Guler, Dominique Vesin, Maria L. Olleros, Pierre Vassalli, \\ Yolande Chvatchko, Muazzam Jacobs, and Bernhard Ryffel
}

Department of Pathology (IG, RG, DV, MLO, PV), Centre Medical Universitaire, University of Geneva, and Serono Pharmaceutical Research Institute (YC), Geneva, Switzerland; and Department of Immunology (MJ, BR), University of Cape Town, Cape Town, South Africa

SUMMARY: The role of nitric oxide (NO) in Mycobacterium bovis Bacillus Calmette Guérin (BCG) infection was investigated using nitric oxide synthase 2 (nos2)-deficient mice, because NO plays a pivotal protective role in M. tuberculosis infection. We demonstrate that nos2-deficient mice were unable to eliminate BCG and succumbed within 8 to 12 weeks to BCG infection (10 CFU) with cachexia and pneumonia, whereas all infected wild-type mice survived. The greatest mycobacterial loads were observed in lung and spleen. Nos2-deficient mice developed large granulomas consisting of macrophages and activated T cells and caseous necrotic lesions in spleen. The macrophages in granulomas from nos2-deficient mice had reduced acid phosphatase activities, suggesting that NO is required for macrophage activation. The absence of NOS2 affected the cytokine production of the Th1 type of immune response, except IL-18. Serum amounts of IL-12p40 were increased and IFN- $\gamma$ was decreased compared with wild-type mice. The lack of NOS2 resulted in an overproduction of TNF, observed throughout the infection period. Additionally, TNFR1 and TNFR2 shedding was altered compared with wild-type mice. Up-regulation of TNF may be compensatory for the lack of NOS2. The late neutralization of TNF by soluble TNF receptors resulted in heightened disease severity and accelerated death in nos2-deficient mice but had no effect in wild-type mice. In conclusion, the inability of nos2-deficient mice to kill M. bovis BCG resulted in an accumulation of mycobacteria with a dramatic activation of the immune system and overproduction of pro-inflammatory cytokines, which resulted in death. (Lab Invest 2000, 80:1385-1397).

\begin{abstract}
$M$ ycobacterium bovis (M. bovis) Bacillus Calmette Guérin (BCG) is a facultative intracellular bacillus that causes diseases in immunodeficient patients. Live M. bovis BCG vaccine is normally well tolerated, however, in children with severe immunodeficiency or mutations of the interferon- $\gamma \mathrm{R} 1$, IL-12, or IL-12R genes, vaccination or infection with BCG leads to lethal dissemination or severe infection (Altare et al, 1998a, 1998b; Casanova et al, 1995; de Jong et al, 1998; Jouanguy et al, 1996, 1997, 1999). Cytokines controlling susceptibility to $M$. tuberculosis and $M$. bovis infections have been extensively studied in genetically modified animals. Mice unable to produce or respond to IFN- $\gamma$ succumb to mycobacterial infections (Cooper et al, 1993; Dalton et al, 1993; Flynn et al, 1993; Kamijo et al, 1993, 1994). Similarly, IL-12 p40
\end{abstract}

Received April 19, 2000.

This work was supported by Grant 3200-054401.98 (to IG) from the Swiss National Foundation for Scientific Research, the Société Academique de Genève, Medical Research Council, Pretoria, funds from the University of Cape Town, and South African Medical Research Council.

Address reprint requests to: Dr. I. Garcia, Department of Pathology, Centre Medical Universitaire, 1, rue Michel-Servet, 1211 Geneva 4, Switzerland. Fax: 41227025 746; E-mail: Garcia@cmu.unige.ch
-/- mice were not able to control M. tuberculosis or M. bovis infections (Cooper et al, 1997; Wakeham et al, 1998). Finally, the role of TNF- $\alpha$ has been documented by TNF- $\alpha$ neutralization with antibodies or the sTNFR1-Ig fusion protein. The neutralization of TNF- $\alpha$ increased the sensitivity to $\mathrm{M}$. bovis and $\mathrm{M}$. tuberculosis infections by inhibiting macrophage differentiation and hence granuloma formation (Adams et al, 1995; Garcia et al, 1997; Kindler et al, 1989). The action of TNF- $\alpha$ was mediated by TNFR1 (Flynn et al, 1995a). A common factor among animals highly susceptible to mycobacteria infection is a reduced activity of the nitric oxide synthase 2 (NOS2 or iNOS) enzyme, which plays a pivotal role in $\mathrm{M}$. tuberculosis infection as demonstrated in nos2 knockout mice. Mice with a targeted disruption of the nos2 gene were highly susceptible to $M$. tuberculosis infection; they had faster replication of bacilli and died earlier than heterozygous or control mice (MacMicking et al, 1997).

Protective immunity against mycobacteria requires an efficient cell-mediated immune response with granuloma formation and macrophage activation. The synergistic action of TNF- $\alpha$ and IFN- $\gamma$ is essential for the differentiation of macrophages with activation of NOS2 leading to the production of $\mathrm{NO}$ and reactive 
nitrogen intermediates (RNI); this represents a strong bactericidal system (Chan et al, 1992; Fang, 1997). Inhibition of NO or RNI production by NOS inhibitors during acute or latent tuberculosis led to a rapid fatal disease progression or to reactivation of latent disease associated with an increased bacterial burden (Chan et al, 1995; Flynn et al, 1998). Although the requirement of $\mathrm{NO}$ for the control of $\mathrm{M}$. tuberculosis infection has been demonstrated, the roles of NOS2, $\mathrm{NO}$, and $\mathrm{RNI}$ in cellular immunity against $\mathrm{M}$. bovis BCG and granuloma formation have not been investigated. Differential susceptibility of mouse strain to BCG infection has been correlated to distinct activation of NOS2 and NO production by macrophages (Barrera et al, 1994; Yoshida et al, 1995) and an inhibitor role of $\mathrm{NO}$ in granuloma organization has been reported (Kreuger et al, 1998).

We used nos2-deficient mice to explore the importance of NOS2 action in host defense mechanisms against $\mathrm{M}$. bovis BCG infection. We found that NOS2 is a critical host defense enzyme controlling cellmediated immunity in $\mathrm{M}$. bovis BCG infection. Without NOS2, mice developed a dramatic granulomatous response with massive cell recruitment, tissue necrosis, and lack of Th1 cytokine regulation. Additionally, macrophages did not acquire mycobactericidal functions, which resulted in fatal necrotic lesions in the spleen accompanied by bacillus overgrowth.

\section{Results}

\section{Nos2-deficient Mice Are Highly Sensitive to BCG Infection Because of Impaired Control of Bacterial Growth}

Inoculation of wild-type mice with M. bovis BCG leads to nonlethal and self-limiting infection. The protective host response is accompanied by NOS2 activation and NO production during the course of the infection (Barrera et al, 1994; Garcia et al, 1997; Yoshida et al, 1995). Here, NOS activity was analyzed in the spleens of wild-type and nos2-deficient mice by measuring the conversion of radioactive $L$-Arginine to $L-C$ itrulline and NO (Bredt and Snyder, 1989). After 4 weeks of $M$. bovis BCG infection ( $10^{6} \mathrm{CFU}$, iv), there was a large increase of NOS activity in the spleen of wild-type mice, and NOS activity was not detected in nos2deficient mice (Fig. 1A). This confirms the lack of NOS2 function in the spleen of nos2-deficient mice during the course of BCG infection.

The sensitivity of nos2-deficient mice to BCG infection was evaluated by iv injection of $10^{6}$ living $M$. bovis BCG. Although control mice $(n=8)$ injected with $\mathrm{M}$. bovis BCG did not present any symptoms, nos2deficient mice $(n=8)$ became progressively cachectic and died 8 to 12 weeks after inoculation (Fig. 1B). Examination of infected organs 6 weeks after BCG infection showed splenomegaly with 2-fold increases in size and weight compared with wild-type mouse spleen. The spleen, lung, and less frequently the liver displayed large white spots corresponding to enlarged granuloma formation. Splenomegaly and hepatomeg-
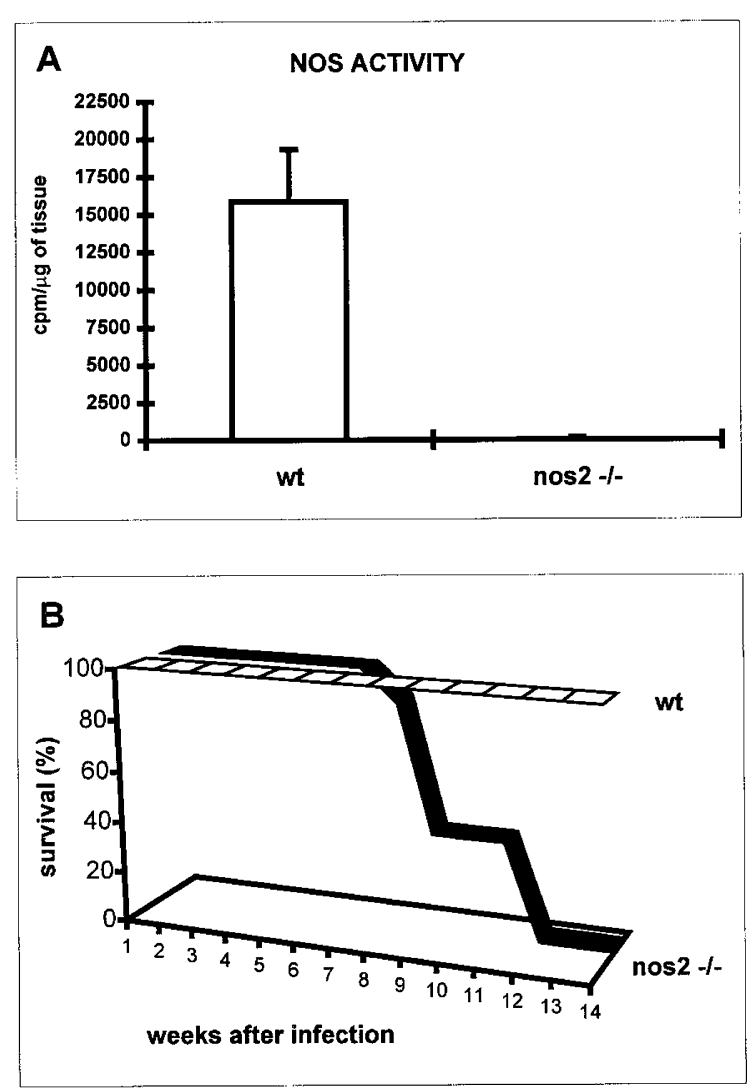

Figure 1.

$A$, NOS activity in the spleen of BCG-infected wild-type mice and its absence in nos2-deficient mice. NOS activity was determined in spleen enzyme extracts from wild-type $(n=4)$ and nos2-deficient mice $(n=4)$. Data are expressed as mean \pm SEM of the $\mathrm{cpm}\left(\mathrm{C}^{14}\right)$ per microgram of tissue. Differences between wild-type and nos2-deficient mice were statistically significant, $p \leq 0.005$. $B$, High sensitivity of nos2-deficient mice to BCG infection. Survival curve of BCG-infected mice: wild-type $(n=8)$ and nos2-deficient mice $(n=8)$ mice were inoculated with $10^{6} \mathrm{BCG}$ per mouse and survival was followed for more than 25 weeks.

aly were observed in nos2-deficient mice 8 weeks after BCG infection but not in wild-type mice.

Groups of nos2-deficient $(n=4)$ and wild-type $(n=$ 4) mice were killed 1,28 , or 56 days after BCG infection. Colony-forming units (CFU) were determined in lungs, spleen, and liver. $M$. bovis BCG growth seemed completely uncontrolled in the lungs of nos2-deficient mice (Fig. 2). Spleens and livers from nos2-deficient mice also had higher CFU counts than organs from wild-type mice 28 and 56 days after infection. This demonstrates that NOS2 was required to control M. bovis BCG infection, as was previously shown for M. tuberculosis infection (MacMicking et al, 1997).

\section{Nos2-Deficient Mice Show Large BCG Granulomas, Decreased Acid Phosphatase Activity, and Extensive Necrotic Lesions in the Spleen}

Groups of nos2-deficient $(n=10)$ and wild-type ( $n=$ 10) mice were infected with $10^{6}$ living $B C G$ and killed 2,4 , and 6 weeks after infection to study granuloma formation in liver, lung, and spleen. Histologic analysis 

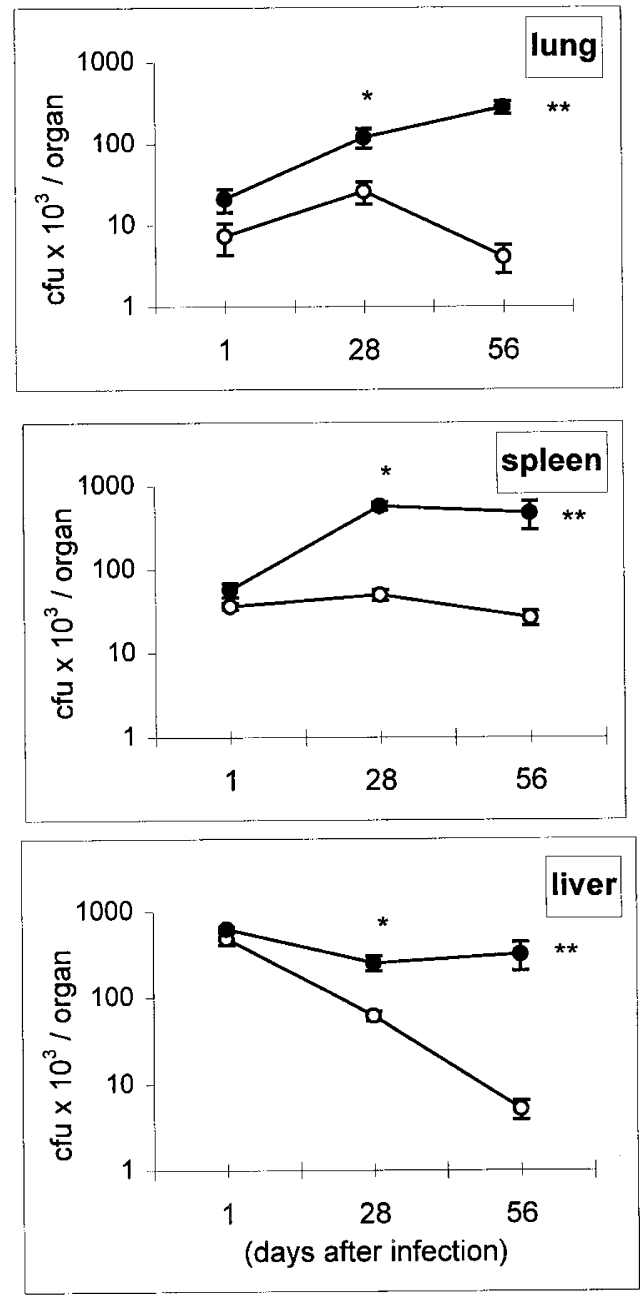

Figure 2.

Determination of M. bovis CFU in lung, spleen, and liver of wild-type (open circles) and nos2-deficient mice (closed circles) 1, 28, and 56 days after inoculation with $10^{6}$ living BCG. Each point represents the mean CFU with SEM from four mice. ${ }^{\star} p<0.02 ;{ }^{* \star} p<0.002$.

of the number and cellular structure of granulomas showed no marked differences between nos2deficient and wild-type mice 2 weeks after infection. Four weeks after infection, the size of hepatic granulomas of nos2-deficient mice was twice as large as control mice. Although hepatic granulomas of wildtype mice in tissue sections contained welldifferentiated epithelioid cells with strong acid phosphatase activity, those of nos2-deficient mice were constituted of large accumulations of macrophages with little epithelioid differentiation or acid phosphatase activity (Fig. 3, A and B). Spleen granulomas were larger in nos2-deficient mice than in wild-type mice. Acid phosphatase was strong in macrophages forming granulomas in wild-type mice, and very weak or absent in the enlarged splenic granulomas of nos2deficient mice (Fig. 3, C and D). Acid phosphatase activity was also evaluated in crude extracts from spleen of wild-type and nos2-deficient mice 4 weeks after BCG infection, and was increased in wild-type mice but not in nos2-deficient mice (Fig. 4).
Frozen tissue sections from livers of nos2-deficient and wild-type mice 4 weeks after BCG infection were analyzed by immunohistochemistry to evaluate the granuloma-forming cells. In nos2-deficient mice, the giant hepatic granulomas contained abundant $\mathrm{F} 4 / 80^{+}$ macrophages and $\mathrm{CD}^{+} \mathrm{T}$ cells at their margins and had strong CD11b and CD11c macrophage expression (Fig. 5). ICAM-1, VCAM-1, and class II antigen expression was also increased in the absence of NOS2, and iNOS was not detectable (data not shown). These results indicate that the recruitment and partial activation of mononuclear cells are enhanced, whereas the terminal differentiation into mycobactericidal epithelioid type macrophages is blocked in the absence of NOS2.

Six weeks after BCG infection, granulomas in the lung and spleen of nos2-deficient mice were very large. In the spleen, particularly, these giant granulomas were characterized by a central cavity surrounded by massive necrosis associated with numerous acid fast bacilli, as shown in Figure 6F. Lung granulomas were also very large compared with lung granulomas from wild-type mice (Fig. 6A), as seen in Figure 6B, showing a lung granuloma from a nos2deficient mouse. Thus, there was an exacerbated cellular immune response, but it was inefficient without NOS2, and led to tissue destruction.

\section{BCG-Infected Nos2-Deficient Mice Up-Regulate Serum Levels of IL-12p40 But Down-Regulate IFN- $\gamma$ Levels}

BCG infection induces activation of cytokines of the Th1 type of immune response. To investigate whether cytokine production during the acute phase of the infection was modified by the lack of NOS2, we analyzed the serum levels of IFN- $\gamma, \mathrm{IL}-12 \mathrm{p} 40$, and IL-18 because these cytokines are required for the host defense against mycobacteria (Cooper et al, 1997; Flynn et al, 1995b; Sugawara et al, 1999; Wakeham et al, 1998). Blood samples for cytokine evaluation by ELISA were collected before BCG infection and 2 and 4 weeks after infection. Serum levels of IL-12p40 were significantly higher in nos2-deficient mice 2 and 4 weeks after infection relative to wild-type mice levels (Fig. 7). The levels of IL-18 in nos2-deficient mice were similar to wild-type levels. In contrast, IFN- $\gamma$ serum levels were decreased in nos2deficient mice compared with levels in wild-type mice, 2 weeks after BCG infection (Figure 7). These results show an important alteration of the Th1 type of immune response in nos2-deficient mice, with up-regulation of IL-12p40 without early activation of IFN- $\gamma$.

\section{Altered Serum Levels of TNF and TNF Receptors in Nos2-Deficient Mice during BCG Infection}

Serum levels of TNF- $\alpha$ were evaluated by ELISA and bioactivity on WEHI 13 cells. Two and four weeks after infection, TNF serum levels were significantly increased in nos2-deficient mice compared with wildtype mice (Fig. 8). In contrast, toxicity of TNF was very low and similar in serum from either wild-type or nos2-deficient mice (2 weeks after infection: $11.08 \pm$ 

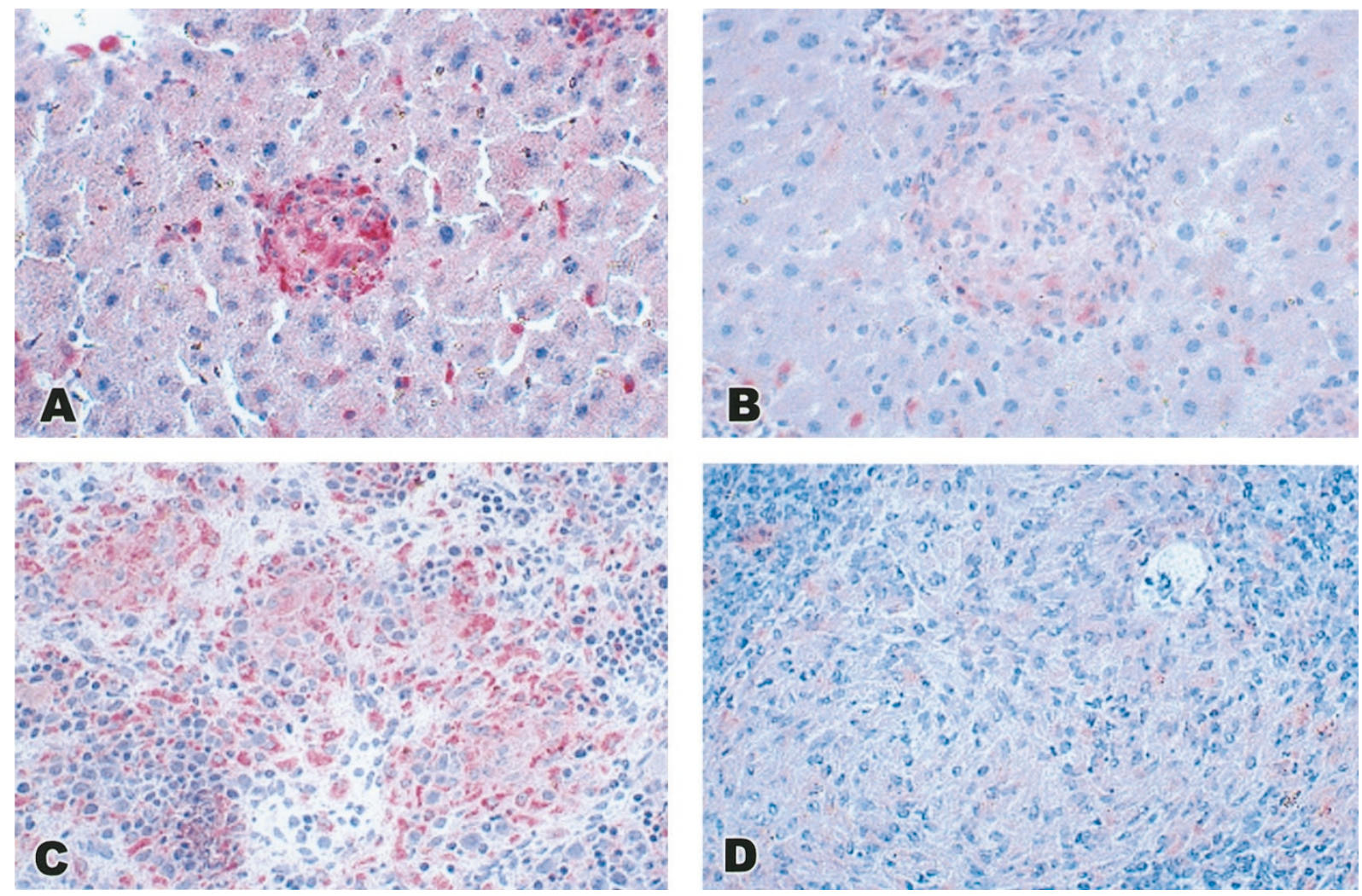

\section{Figure 3.}

Histologic appearance of liver $(A$ and $B)$ and spleen $(C$ and $D)$ sections stained for acid phosphatase activity 4 weeks after BCG infection. $A$, Strong acid phosphatase activity in the BCG-granuloma of wild-type mice corresponding to activated macrophages. Granulomas were well delimited, numerous, and had strong acid phosphatase staining. $B$, In nos2-deficient mice, the size of granulomas was much larger, and contained many macrophages, but acid phosphatase staining was less intense. $C$, Acid phosphatase activity in normal splenic granulomas, which are numerous and have high enzyme activity. $D$, One enlarged granuloma from a nos2-deficient mice that does not show acid phosphatase activity. These results are representative of four mice per group and two experiments.

$4.69 \mathrm{pg} / \mathrm{ml}$ in control mice versus $8.50 \pm 4.99 \mathrm{pg} / \mathrm{ml}$ in nos2-deficient mice). These data indicate that the majority of released TNF was neutralized by soluble TNF receptors. To examine whether NOS2 influences TNF receptor shedding, we assessed the amounts of soluble TNF receptors during infection. In wild-type mice, shedding of TNFR1 and TNFR2 was increased 2 weeks after infection and decreased 4 weeks after infection. In contrast, in nos2-deficient mice, the kinetics were different, with a progressive increase of both soluble TNF receptors. Serum levels of TNFR1 were significantly decreased two weeks after infection compared with wild-type mice. Serum levels of TNFR2 were similar between the groups two weeks after infection, and significantly increased in nos2-deficient mice compared with wild-type mice 4 weeks after infection (Fig. 8). These data show that TNF receptor shedding is modified in nos2-deficient mice, TNFR1 release is delayed, and TNFR2 release is up-regulated. We also found that the amounts of TNFR always exceeded TNF levels during infection.

\section{sTNFR1 Treatment of BCG-Infected Nos2-Deficient Mice Results in a Still Increased Susceptibility to BCG Infection Leading to Rapid Death}

BCG-infected animals were treated with murine soluble TNFR1-IgG fusion protein to investigate whether the BCG-induced TNF increase in nos2-deficient mice plays a deleterious or beneficial role. Three weeks after infection, murine either TNFR1-lgG1 or lgG1 was injected into BCG-infected nos2-deficient mice (100 $\mu \mathrm{g} /$ mouse, ip; $n=3$ ). After three injections of sTNFR1$\mathrm{Ig}$, nos2-deficient mice were very sick and died approximately 6 or 7 weeks after BCG-infection, whereas nos2-deficient mice treated with control protein died 8 to 12 weeks after infection (Fig. 1).

In a second experiment, we injected a human sTNFR1-Ig (produced in transgenic mice) as the TNF antagonist (Garcia et al, 1995), 3 weeks after BCG infection. Nos2-deficient $(n=5)$ and wild-type mice $(n=5)$ were treated weekly with $50 \mu \mathrm{g}$ or $25 \mu \mathrm{g}$ of TNFR-Ig or control protein per mouse. Treatment with $50 \mu \mathrm{g}$ of TNFR-Ig resulted in accelerated death of nos2-deficient mice $(n=5)$ after three or four injections, as in the previous experiment. In contrast, wild-type mice $(n=5)$ were not affected by the $50 \mu \mathrm{g}$ dose after five injections; all of these mice survived the treatment. Nos2-deficient mice treated with $25 \mu \mathrm{g}$ of sTNFR1 were sick (one mouse died at the 7 th week) and lost weight more rapidly than nos2-deficient mice injected with control proteins. In contrast, wild-type mice were not affected by this treatment (Fig. 9). Histologies of the spleen of nos2-deficient mice 8 weeks after BCG infection had massive caseous ne- 


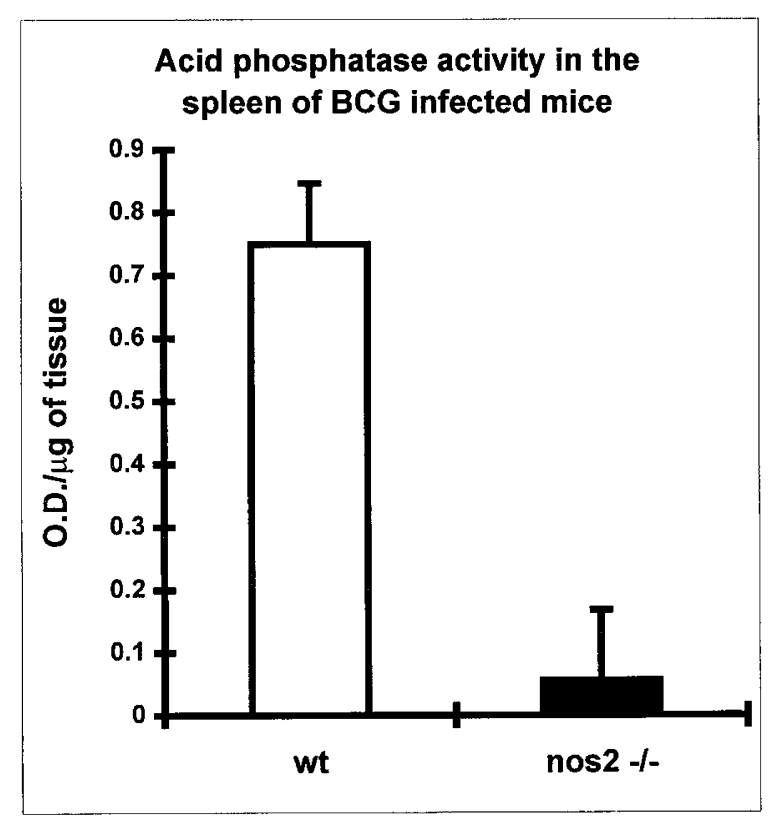

Figure 4.

Acid phosphatase in spleen protein extracts from BCG-infected wild-type and nos2-deficient mice. Spleens from wild-type and nos2-deficient mice were collected 4 weeks after BCG infection. Results are expressed as means of the OD $(570 \mathrm{~nm}) \pm$ SEM from four different samples per group. Spleen acid phosphatase activity from uninfected wild-type and nos2-deficient mice were similar (wild-type: $0.506 \pm 0.047$; nos2-deficient: $0.487 \pm 0.011$ ); these values were subtracted from the presented data). Experimental groups were statistically significant, $p<0.05$.

crosis in both groups of nos2-deficient mice (data not shown). TNF and TNFR serum levels were measured 8 weeks after BCG infection, 1 week after the last dose of sTNFR1-lg. The serum amounts of total TNF in nos2-deficient mice were more than 10 times higher than those in wild-type mice $(p<0.002)$, however, treatment with $25 \mu \mathrm{g}$ of sTNFR1-lg did not change TNF levels in either wild-type or nos2-deficient mice (Figure 9). Serum levels of TNFR1 and TNFR2 were also higher in nos2-deficient mice than in wild-type mice (Fig. 9, E and F). These data suggest that nos2-deficient mice up-regulate TNF during the infection as a compensatory mechanism for the lack of NOS2 activity, and that excessive TNF production confers protection, which can be abrogated by neutralization with STNFR1.

\section{Discussion}

The results from the present study demonstrate that $N O$ is required for defense against attenuated $M$. bovis $B C G$ infection. A relatively small dose of $\mathrm{M}$. bovis BCG $\left(10^{6}\right)$ was lethal in nos2-deficient mice because of an enhanced cellular immune response as observed by tissue necrosis, cytokine overproduction, and lack of well-differentiated granulomas. These results agree with previous data from $M$. tuberculosis infection and emphasize the importance of NOS2 in mycobactericidal pathways (MacMicking et al, 1997).

The present work showed that the lungs and spleen were the most affected organs in nos2-deficient mice.
Predominant pulmonary lesions and heavy bacterial burden were also reported in mice treated with NOS inhibitors during late M. tuberculosis infection (Flynn et al, 1998). In contrast, the livers of nos2-deficient mice were able to control bacillus proliferation. These results suggest that although $\mathrm{NO}$ and RNI production are crucial mechanisms of alveolar macrophages, a NOS2-independent mechanism, eg, involving phagocyte oxydase (Shiloh et al, 1999), may be involved in regulating the mycobactericidal pathway in liver BCG granulomas.

In spleens of nos2-deficient mice, BCG rapidly proliferates, leading to caseous necrosis with a central cavity, which is a consequence of the failure of adequate granuloma differentiation. This extensive necrosis may reflect the death of cells unable to control mycobacterial growth past the bactericidal capacity of granulomas together with the accumulation of cellular and bacterial products. This form of necrosis has never been observed in spleens of BCG-infected mice, even where mice were unable to use TNF- $\alpha$ and IFN- $\gamma$; eg, IFN- $\gamma \mathrm{R}$-deficient mice expressing a soluble TNFR1 transgene (Garcia et al, 1997). We have previously observed extensive splenic necrosis and BCG overgrowth in sTNFR1 transgenic mice treated with soluble LT- $\beta$ R recombinant protein, leading to neutralization of TNF- $\alpha$, LT- $\alpha$, the membrane LT- $\beta / \alpha$ and LIGHT. Treatment of normal mice with LT- $\beta$ R greatly decreased NOS activity in the spleen of BCG-infected mice (Lucas et al, 1999). These data demonstrate the requirement of NOS2 in granuloma formation in the spleen and in the control of the cellular immune response limiting tissue destruction.

After BCG infection, early granulomas in nos2deficient mice were similar to those of control mice. However, granulomas of wild-type mice were functional and able to kill BCG, whereas in nos2-deficient mice, numerous bacilli were present and there was exaggerated cellular recruitment leading to giant granulomas in liver, spleen, and lungs. Infiltrating cells were mainly macrophages and activated T cells, and, compared with control mice, had increased expressions of class II antigen, the adhesion molecules ICAM-1 and VCAM-1, and the integrins CD11b and CD11c. In nos2-deficient mice, there was a lack of macrophage activation, contrasting with the excessive cellular infiltration. Macrophages forming granulomas differentiate into epithelioid cells and acquire the capacity to destroy internal bacilli accompanied by expression of high levels of acid phosphatase activity and activation of NOS2. Acid phosphatase was reduced in liver granulomas and mainly absent in the spleens of nos2-deficient mice. These data suggest that $\mathrm{NO}$ is involved in macrophage differentiation and involved in homeostasis of the cellular immune response by limiting mediators and cell recruitment to infected organs.

BCG infection induces IL-12 expression, which promotes the Th1 cell type immune response and activates IFN- $\gamma$ production by $\mathrm{NK}$ and $\mathrm{T}$ cells. BCG infection of nos2-deficient mice resulted in high levels of IL-12p40 and low levels of IFN- $\gamma$ relative to levels in 

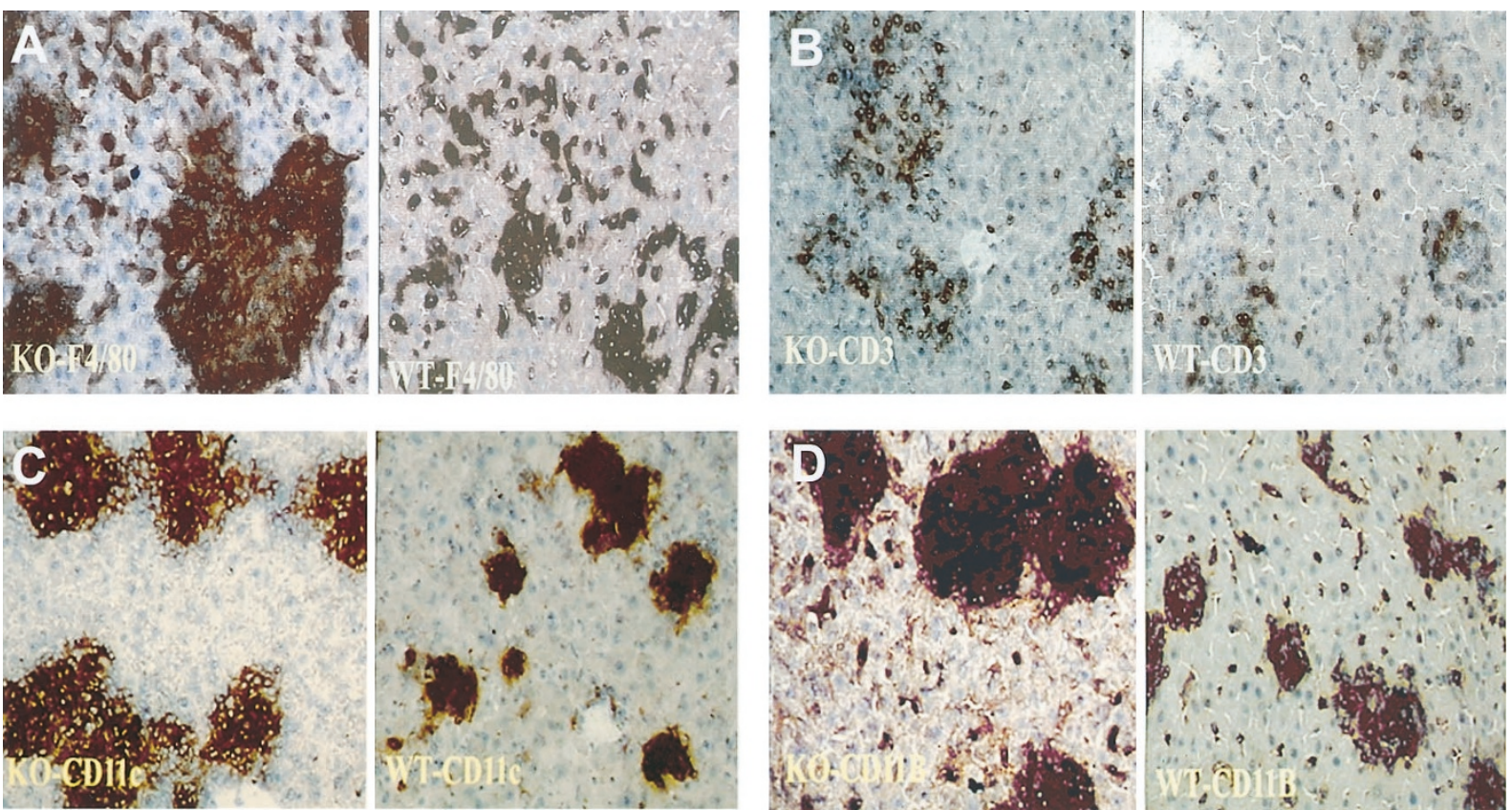

\section{Figure 5 .}

Immunohistochemistry of liver sections from wild-type and nos2-deficient mice 4 weeks after BCG inoculation. A, Liver granulomas from nos2-deficient and wild-type mice immunoreacted with the $\mathrm{F} 4 / 80$ antibody. In nos2-deficient mice, large (giant) granulomas containing abundant F4/80 positive macrophages were observed. $B$, $\mathrm{CD}^{+} \mathrm{T}$ cells at the margin of a large granuloma. $C$ and $D, C D 11 \mathrm{C}$ and $\mathrm{CD} 11 \mathrm{~b}$ immunoreactivity showing strong expression of these integrins on the macrophages of the granulomas. Original magnification, $\times 100$.

wild-type mice. NOS2 seems to be involved in the regulation of IL-12 levels and in modulating IL-12R signaling and IFN- $\gamma$ production. NO has been reported to down-regulate IL-12 (Rothe et al, 1996). Huang et al (1998) showed that NO acts as an inhibitor of the feedback loop of IL-12 that induces Th1 cells to produce IFN- $\gamma$, which activates macrophages to produce IL-12, and thus prevents the excessive amplification of Th1 cells involved in many immunopathologies. Additionally, IL-12 administration activated host inflammatory cytokines in chimpanzees (Lauw et al, 1999) and induced hepatic cellular infiltrates in mice that were similar to infiltrates found in IFN- $\gamma \mathrm{R}$ knockout mice (Car et al, 1995). Our results suggest that high levels of IL-12 contribute to the excessive recruitment of inflammatory cells and the tissue destruction in infected organs of nos2-deficient mice. Pertinent to the low levels of IFN- $\gamma$ observed in nos2-deficient mice after infection, Diefenbach et al (1999) showed that NOS2 was required for IL-12-induced IFN- $\gamma$ production by NK cells because NOS-2-derived NO was necessary for activation of Tyk2 kinase and tyrosine phosphorylation of Stat4. The low levels of IFN- $\gamma$ observed in nos2-deficient mice early in BCG infection may be explained by the NOS2 deficiency causing a failure of signal transduction for IL-12 in NK cells.

BCG infection induced TNF, which was overproduced in nos2-deficient mice. Regulation of $\mathrm{NO}$ and TNF has been extensively studied in both in vitro and in vivo model systems. Depending on the cellular system, after lipopolysaccharide (LPS) challenge, NO decreased TNF production (Eigler et al, 1995; luvone et al, 1996; Peng et al, 1995; Thomassen et al, 1997) or increased TNF synthesis (Huang et al, 1998). Recent reports have shown that NO blocks nuclear factor- $\kappa \mathrm{B}$ activation in alveolar macrophages. Indeed, inhibition of NOS2 resulted in an increase of proinflammatory cytokines including TNF, IL-12, IL-8, and granulocytemacrophage colony-stimulating factor (GM-CSF) (Fowler et al, 1999; Raychaudhuri et al, 1999; Walley et al, 1999). Our data agrees with previous studies on the regulatory mechanisms of cytokines mediated by NO.

TNF production was followed by TNF receptor shedding and most cytotoxic TNF was rapidly neutralized by soluble receptors. The serum amounts of soluble TNFR always exceeded TNF levels during infection. The lack of TNF toxicity in the circulation does not totally exclude the possibility that it could still be toxic in infected organs. Although the levels of sTNFR1 were transiently decreased in nos2-deficient mice compared with wild-type mice, the serum levels of STNFR2 were similar in both groups of mice 2 weeks after infection and significantly increased in nos2-deficient mice 4 weeks after infection. The endogenous balance of TNF and soluble TNF receptors in the modulation of cachexia and mortality in mice acutely infected with Tryposoma cruzi infection is important; the lowest levels of sTNFR1-TNF are associated with high parasitemia and death (Truyens et al, 1999). Inactivation of TNF by release of TNFR2 has been proposed as a mechanism for $\mathrm{M}$. tuberculosis to avoid apoptosis of host macrophages (BalcewiczSablinska et al, 1998). TNFR1 shedding is also an essential step involved in apoptosis-induced inhibition of TNF signal transduction (Madge et al, 1999). In nos2-deficient mice, we found that early in infection, 

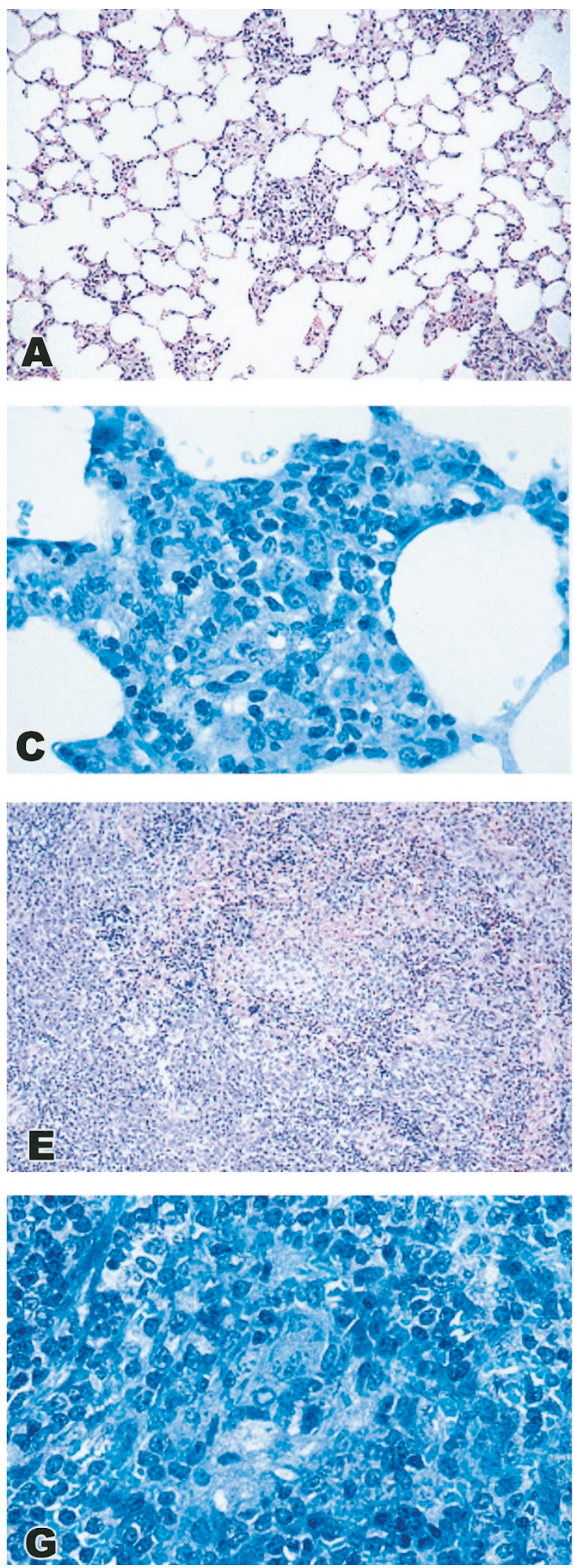
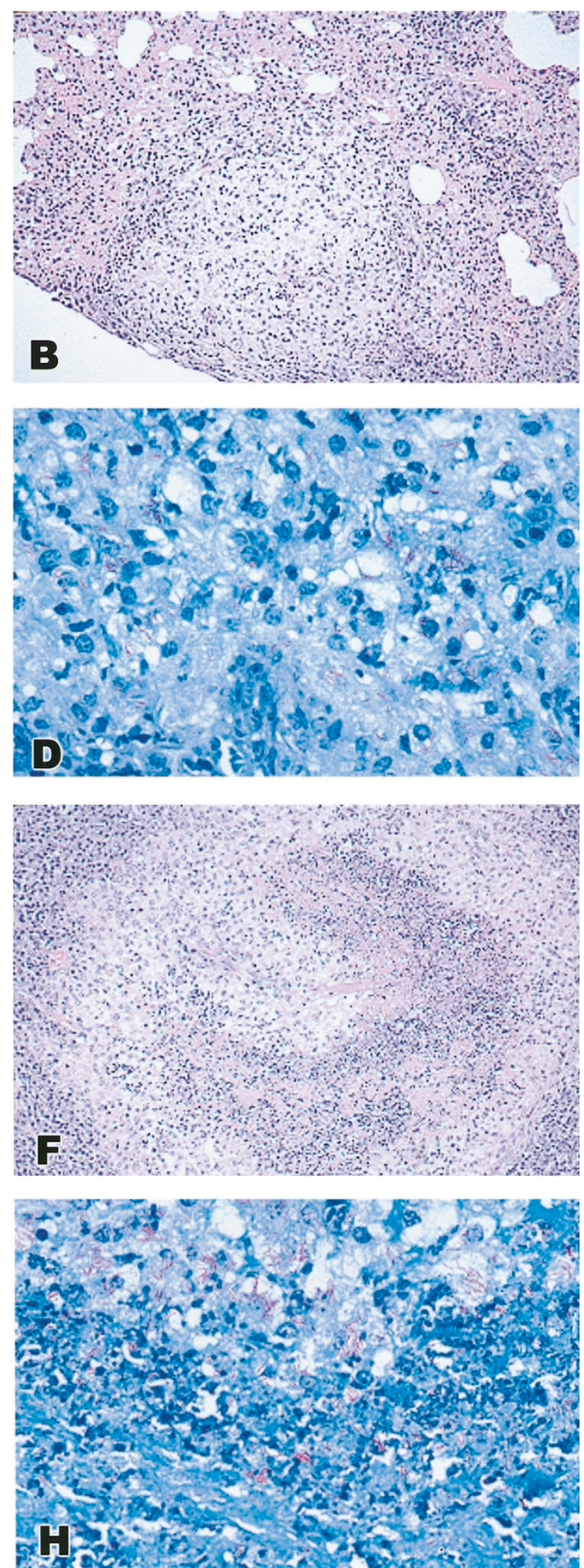

\section{Figure 6.}

Histologic appearance of lung $(A$ to $D)$ and spleen $(E$ to $H)$ sections from wild-type $(A, C, E$, and $G)$ and nos2-deficient $(B, D, F$, and $H)$ mice obtained 6 weeks after $B C G$ infection and stained with hematoxylin and eosin $(A, B, E$, and $F$, and with Ziehl-Neelsen $(C, D, G$, and $H)$. Nos2-deficient mice have large $B C G$ granulomas in lung $(B)$. Histologic sections of spleen from nos2-deficient mice with a caseous necrotic lesion $(F)$ compared with the small granuloma in the spleen of wild-type mice. Numerous acid fast bacilli (AFB) are present in necrotic lesions in spleens from nos2-deficient mice $(H)$. Original magnifications, $A, B, E$, and $F$ : $\times 80 ; C, D, G$, and H: $\times 320$. 

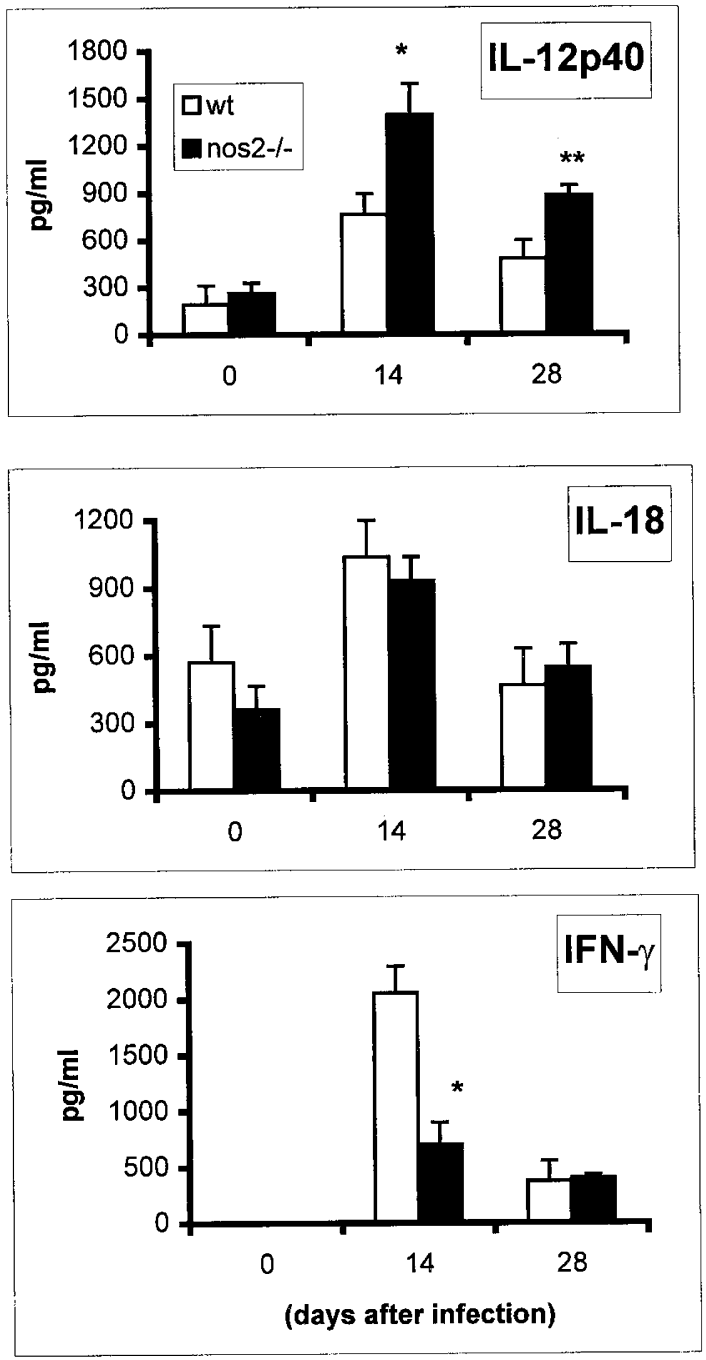

\section{Figure 7.}

Production of Th1 cytokines is altered in nos2-deficient mice after BCG infection. IL-12p40, IL-18, and IFN- $\gamma$ in the serum of wild-type $(n=5)$ and nos2-deficient $(n=5)$ mice were evaluated by ELISA. Results are expressed as mean picograms of protein per milliliter of serum \pm SEM. Results are representative of two to three independent experiments. ${ }^{\star} p<0.01 ;{ }^{\star *} p<$ 0.02 .

the shedding of TNFR1, the main receptor on macrophages, is decreased. This suggests a role of NOS2 in this process. The shedding of TNFR2, mainly expressed on stimulated lymphocytes, is increased concomitantly with inflammatory cellular recruitment. Our data indicate that NOS2 is involved in both TNF regulation and TNFR shedding.

TNF up-regulation seemed beneficial for nos2deficient mice and conferred a relative protection in nos2-deficient mice during the infection. Thus, administration of TNFR1-IgG recombinant proteins accelerated the death of infected mice. Because TNFR1 and TNFR2 also neutralize lymphotoxins, we cannot exclude a contribution of lymphotoxins in host defense during BCG infection as previously reported for membrane LT $\alpha 1 / \beta 2$ (Lucas et al 1999). We also showed that administration of TNFR1-IgG was detrimental for
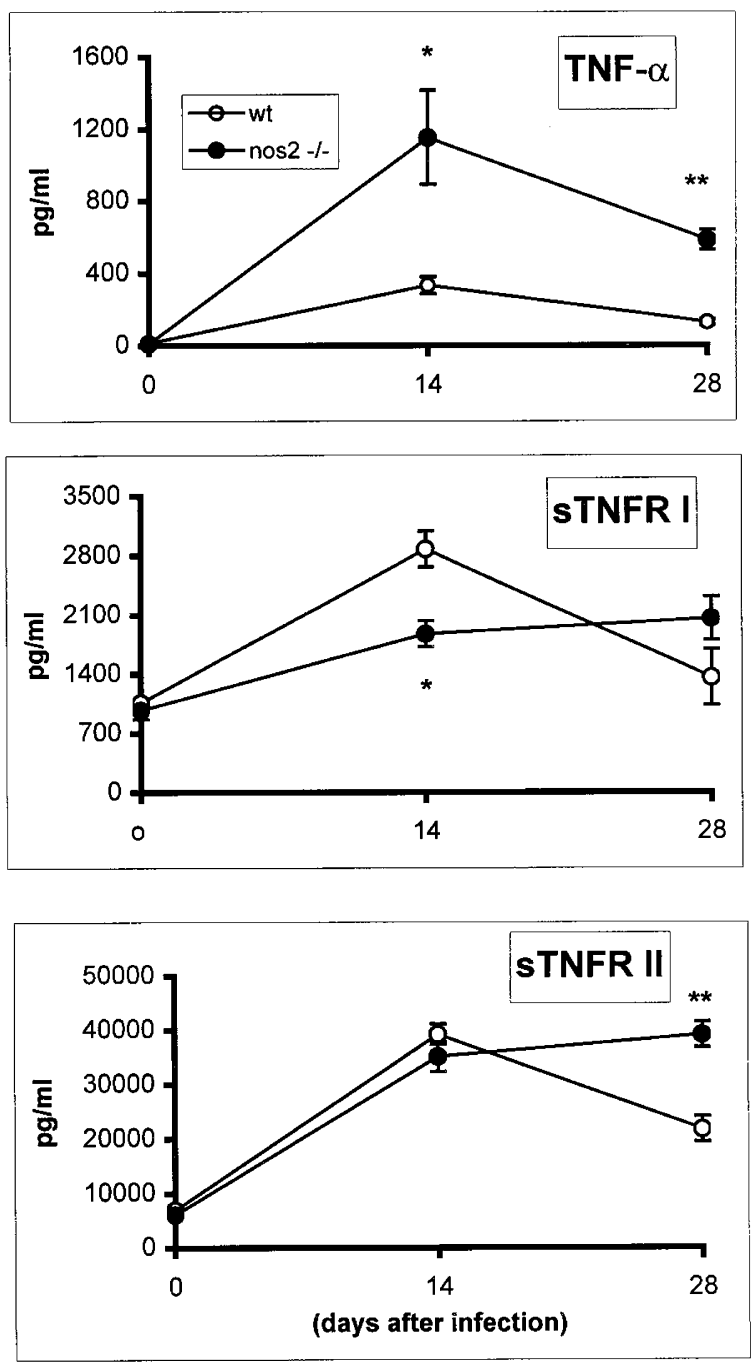

Figure 8.

Nos2-deficient mice produce large amounts of TNF and have altered TNFR1 and TNFR2 shedding after BCG infection. TNF was evaluated by ELISA in the serum of wild-type and nos2-deficient mice, before infection $(n=5)$, and at 14 days ( $n=13$ to 14 ) and 28 days ( $n=7$ to 9 ) after infection. Results are expressed as mean picograms of protein per milliliter of serum \pm SEM, derived from at least two independent experiments. ${ }^{\star} p<0.002 ;{ }^{* \star} p<0.000001$. Serum levels of soluble TNFR1 and TNFR2 during BCG infection were determined at different times after BCG infection $(n=5)$. Results are expressed as mean picograms of protein per milliliter of serum \pm SEM. ${ }^{*} p<$ $0.002 ;{ }^{*} p<0.001$.

infected mice but did not affect circulating amounts of TNF or TNFR in nos2-deficient or wild-type mice.

Our results indicate distinct functions of NOS2 during BCG infection. During the acute phase, NOS2 controls the production of the main cytokines of the innate immune response such as TNF, IL-12, and IFN- $\gamma$, but not IL-18. During the late phase, NOS2 regulates the cellular immune response by limiting cellular recruitment and affects macrophage differentiation leading to the development of antimicrobial activity.

The role of NO was shown before the advent of nos2-deficient mice. Using NOS inhibitors, Chan et al (1992, 1995) first demonstrated a crucial role of nitric oxide in mycobacterial resistance. Flynn et al (1998) 

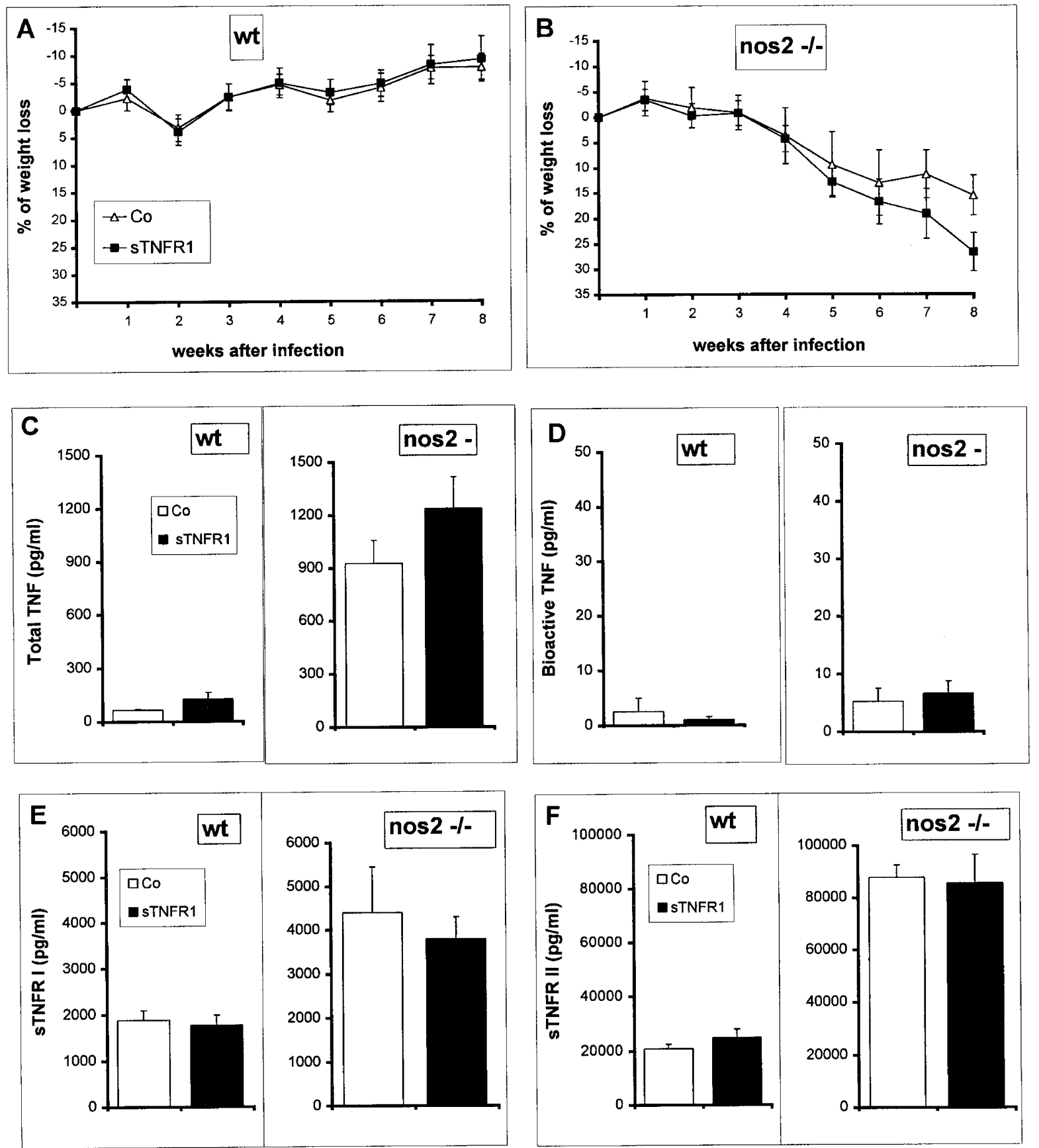

\section{Figure 9.}

Body weight loss and TNF or TNFR serum levels after treatment with STNFR1-Ig. A, Percentages of weight changes during the course of BCG infection in wild-type mice treated with human sTNFR1-lgG (25 $\mu \mathrm{g} /$ mouse) or with normal mouse serum 10 times diluted in PBS. Proteins were injected weekly from 3 to 7 weeks after BCG infection; mice were killed 1 week after the last injection. Results are expressed as mean \pm SD. Four to five mice were used per group. $B$, Weight loss of nos2-deficient mice treated with the same protocol. Nos-2-deficient mice treated with sTNFR1-Ig were moribund at the time of killing, one mouse died at the 7th week after infection. Four to five mice were assessed per group. $C$ and $D$, Evaluations of total and bioactive TNF in wild-type and nos2-deficient mice from the experiment shown in $A$ and $B$ at the time of death, 8 weeks after BCG infection. Results are expressed as means $\pm \operatorname{SEM}(n=3$ to 5$)$. $E$ and $F$, Evaluations of serum amounts of soluble TNFR1 and TNFR2 in wild-type and nos2-deficient mice from the experiment shown in $A$ and $B$ at the time of death, 8 weeks after BCG infection. Results are expressed as means \pm SEM $(n=3$ to 5$)$.

showed that inhibition of NO in latent infection resulted in reactivation, which supports the notion that mycobacterial infection is never eradicated in the host, but requires continued activation of macrophages by the immune system.
The NOS2 requirements in murine BCG infection contrast with previous data in murine $M$. avium infection. M. avium has a low virulence in human and only causes disease in severely immunocompromised individuals (Shiratsuchi et al, 1994). M. avium infection 
does not seem to require the induction of the NOdependent effector pathway to control bacillus growth (Doherty and Sher, 1997). Gomes et al (1999) demonstrated that nos2-deficient mice infected with $M$. avium had an improved clearance of bacilli compared with control mice. In contrast to $M$. bovis BCGinfected nos2-deficient mice, they observed higher IFN- $\gamma$ serum levels in deficient mice than in control mice. This indicates that distinct cellular mechanisms involving NOS2 activation and Th1 cytokines are triggered by BCG and M. avium infections.

In conclusion, our data demonstrate that the absence of NOS2 resulted in an enhanced cellular immune response with increased recruitment of inflammatory cells, reduced macrophage activation, overproduction of pro-inflammatory cytokines, and uncontrolled growth of mycobacteria. Therefore, NO has both immunomodulator and bacteriostatic activities which are required for host defense against mycobacterial infection.

\section{Materials and Methods}

\section{Animals}

C57BL/6 were obtained from BRL (Fuellinsdorf, Switzerland) and nos2 gene-deficient mice (MacMicking et al, 1995) back-crossed onto a C57BL/6 genetic background were obtained from Jackson Laboratories (Bar Harbor, Maine) and maintained under conventional conditions.

\section{BCG Infection}

Wild-type and nos2-deficient male and female mice (8 to 12 weeks old) were infected iv with $10^{6} \mathrm{CFU}$ of $\mathrm{M}$. bovis BCG strain 1173 P2 (a gift from Dr. G. Marchal, Pasteur Institute, Paris, France) and killed at day 1, 14, 28, 42, and 56 after infection.

\section{Cytokine Determination From Serum Samples}

Serum samples were obtained from mice before infection and 2 and 4 weeks after infection. TNF- $\alpha$, IL-12p40, IL-18, and IFN- $\gamma$ levels were evaluated by ELISA with a sensitivity of 2 to $1000 \mathrm{pg} / \mathrm{ml}$ (Ready\&System, Abingdon, United Kingdom). TNF cytotoxicity was determined using a subclone of the WEHI 164 clone 13 cells (Flick and Gifford, 1984). The lower limit of sensitivity was $1 \mathrm{pg} / \mathrm{ml}$.

\section{Histologic Analyses}

Livers, lungs, and spleens were fixed in $4 \%$ buffered formaldehyde, embedded in paraffin, cut at a thickness of $5 \mu \mathrm{m}$, and stained with hematoxylin \& eosin. To detect mycobacteria, the sections were stained with Ziehl-Neelsen staining and counterstained with hematoxylin.

\section{Immunohistochemistry}

Frozen tissues (liver, spleen, and lungs) were cut at a thickness of $6 \mu \mathrm{m}$ on a cryostat and air-dried for storage at $-80^{\circ} \mathrm{C}$. Fixation in acetone (10 minutes at $4^{\circ} \mathrm{C}$ ) was performed before immunohistochemistry. After a rinse in PBS, the sections were incubated for 16 hours at $4^{\circ} \mathrm{C}$ with primary antibodies diluted in PBS. The sections were washed in PBS and incubated for 30 minutes at room temperature with rabbit anti-rat serum ABC system (Vector Lab, Burlingame, California), followed by DAB substrate. After two rinses in PBS, the sections were mounted with Immunomount (Shandon, Pittsburgh, Pennsylvania). The following rat monoclonal antibodies were used: CD3, CD11b, CD11c, and F4/80 (Pharmingen, San Diego, California). Rabbit serum against NOS2 was a gift from Dr. J. Pfeilschifter, Zentrum der Pharmakologie, Frankfurt, Germany.

\section{Determination of CFU in Infected Organs}

Bacterial loads in the lungs, liver, and spleen of infected mice were evaluated 1, 28, and 56 days after infection. Organs were weighed and defined aliquots were homogenized in saline containing $0.04 \%$ Tween 80. Ten-fold serial dilutions of organ homogenates were plated in duplicates onto Middlebrook 7H10 agar plates containing $10 \%$ oleic albumin Dubos complex (OADC) (Difco, Detroit, Michigan). Plates were incubated at $37^{\circ} \mathrm{C}$ for 19 to 21 days and colonies were counted. Data were expressed as the mean CFU +/SD per organ.

\section{Determination of Acid Phosphatase Activity}

Acid phosphatase activity was determined on frozen tissue sections as previously described (Garcia et al, 1997; Kindler et al, 1989). The method used on tissue sections was modified and adapted for detection of acid phosphatase activity on the whole organ, as described in Lucas et al (1999).

\section{Determination of NOS Activity in Spleen Extracts}

Evaluation of the induction of nitric oxide synthase activity was performed on a crude enzyme preparation made from frozen spleen samples. Spleens were homogenized in $25 \mathrm{~mm}$ Tris- $\mathrm{HCl}(\mathrm{pH} 7.4), 1 \mathrm{~mm}$ EDTA, and $1 \mathrm{~mm}$ EGTA ( $0.25 \mathrm{~g}$ of tissue $/ \mathrm{ml}$ of buffer). Crude supernatant was obtained by centrifugation of the homogenate at $10,000 \times g$ for 5 minutes. NOS activity was measured as the ability of the supernatant to convert radioactive $\mathrm{L}-\left({ }^{14} \mathrm{C}\right)$-arginine (Amersham Life Science, Clearbrook, Illinois) to $\mathrm{L}-\left({ }^{14} \mathrm{C}\right)$-citrulline by using a NOSdetect assay kit (Stratagene, Heidelberg, Germany). Five microliters of supernatant was incubated in the presence of $\mathrm{L}-\left({ }^{14} \mathrm{C}\right)$-arginine $(0.05 \mu \mathrm{Ci})$, NADPH (10 mM), tetrahydrobiopterine $(6 \mu \mathrm{M})$, flavin adenine dinucleotide $(2 \mu \mathrm{M})$, flavin adenine mononucleotide $(1 \mu \mathrm{M})$, and $50 \mathrm{~mm}$ Tris- $\mathrm{HCl}, \mathrm{pH} 7.4$, at room temperature for 30 minutes. The reaction mixture was stopped with stop buffer (50 mM HEPES, pH 5.5, and $5 \mathrm{~mm}$ EDTA) and applied to a Dowex 50W column following the recommended protocol (Stratagene). Uninfected wild-type and nos2-deficient mice showed similar NOS activities in spleen extracts; wild-type 
mice: $3.387 \pm 1.331 \mathrm{cpm}$ and nos2-deficient mice: $3.410 \pm 240 \mathrm{cpm}$. These values, which were not blocked by NOS inhibitor (N-nitro-l-arginine methyl ester, $1 \mathrm{~mm}$ ), were subtracted from the presented data.

\section{sTNFR1-Ig Treatment Protocols}

We used fusion proteins comprising the extracellular domain of murine TNF-R55 fused to hinge, $\mathrm{CH} 2$, and CH3 domains of human IgG1 (Lucas et al, 1999). Purified human IgG used as control was purchased from Sandoz (Basel, Switzerland). Mice received 100 $\mu \mathrm{g}$ of human IgG1 or TNF-R55-lgG1 injection in 0.5 $\mathrm{ml}$. The human sTNFR1-lgG protein was prepared from serum of transgenic mice expressing high levels of this protein. The amount of human STNFR1-IgG was determined by ELISA as described in Garcia et al (1995) and tested for bioactivity on WEHI 13 cells. The serum was diluted in PBS approximately 5 to 10 times to obtain concentrations of $100 \mu \mathrm{g} / \mathrm{ml}$ and $50 \mu \mathrm{g} / \mathrm{ml}$, respectively, of sTNFR1-lgG. Serum from negative littermates diluted in PBS following the same conditions was used for the negative control. Mice were infected with BCG and starting 3 weeks after infection were treated weekly $(0.5 \mathrm{ml}$, ip); for 3 to 4 weeks with $100 \mu \mathrm{g}$ per mouse of murine sTNFR1-lg or $50 \mu \mathrm{g}$ of human sTNFR1-lg, and for 5 weeks with the dose of $25 \mu \mathrm{g}$ per mouse of human sTNFR1-lg.

\section{Bioassay for TNF Toxicity on WEHI (Clone 13) Cells}

We measured the effect of the serial dilution of mouse serum samples on WEHI cells compared with standard murine TNF (Flick and Gifford, 1984). WEHI cells $\left(3 \times 10^{4}\right.$ cells per well) were incubated in the presence of actinomycin $D(1 \mu \mathrm{g} / \mathrm{ml})$ with mouse serum (dilutions from $1 / 20$ to $1 / 16,000)$ for 20 hours in a total volume of $100 \mu \mathrm{l}$ per well. One picogram of TNF standard kills $50 \%$ of WEHI cells. Addition of serum from transgenic mice expressing the human TNFR1IgG3 fusion protein inhibited cell lysis and gave values corresponding to those expected from the amounts as evaluated by ELISA (Garcia et al, 1995). Cell viability was assessed by the addition of $20 \mu \mathrm{l}$ per well of MTS/PMS (333 $\mu \mathrm{g} / \mathrm{ml}$ MTS and $25 \mu \mathrm{M}$ PMS) (Promega, Madison, Wisconsin) 3 to 4 hours incubation. Absorbance was directly measured at $490 \mathrm{~nm}$ in a 96-well plate reader.

\section{Statistical Analysis}

Statistical evaluations of differences between results of experimental groups were determined by the use of appropriate frequency analyses with the MannWhitney $U$ test and Student's $t$ test.

\section{Acknowledgements}

The authors are grateful to Ms. C-D. Kan, Mr. S. Jemelin and Mr. C. Vesin, for excellent technical assistance, Ms. G. Levraz, Ms. J. Stalder, and Mr. T. Le Minh for histologic studies, and Mr. J.C. Rumbeli and Mr. E. Denkinger for photographic work. We thank Dr. C.F. Nathan and Dr. J.D. MacMicking for their gift of breeders of nos2-deficient mice.

\section{References}

Adams LB, Mason CM, Kolls JK, Scollard D, Krahenbuhl JL, and Nelson S (1995). Exacerbation of acute and chronic murine tuberculosis by administration of a tumor necrosis factor receptor-expressing adenovirus. J Infect Dis 171:400405.

Altare F, Durandy A, Lammas D, Emile JF, Lamhamedi S, Le Deist F, Drysdale $P$, Jouanguy E, Doffinger R, Bernaudin F, Jeppsson O, Gollob JA, Meinl E, Segal AW, Fischer A, Kumararatne D, and Casanova JL (1998a). Impairment of mycobacterial immunity in human interleukin-12 receptor deficiency. Science 280:1432-1435.

Altare F, Lammas D, Revy P, Jouanguy E, Doffinger R, Lamhamedi S, Drysdale P, Scheel-Toellner D, Girdlestone J, Darbyshire P, Wadhwa M, Dockrell H, Salmon M, Fischer A, Durandy A, Casanova JL, and Kumararatne DS (1998b). Inherited interleukin 12 deficiency in a child with bacille Calmette-Guerin and Salmonella enteritidis disseminated infection. J Clin Invest 102:2035-2040.

Balcewicz-Sablinska MK, Keane J, Kornfeld H, and Remold HG (1998). Pathogenic Mycobacterium tuberculosis evades apoptosis of host macrophages by release of TNF-R2, resulting in inactivation of TNF-alpha. J Immunol 161:26362641.

Barrera LF, Kramnik I, Skamene E, and Radzioch D (1994). Nitrite production by macrophages derived from BCGresistant and -susceptible congenic mouse strains in response to IFN-gamma and infection with BCG. Immunology 82:457-464.

Bredt DS and Snyder SH (1989). Nitric oxide mediates glutamate-linked enhancement of cGMP levels in the cerebellum. Proc Natl Acad Sci USA 86:9030-9033.

Car BD, Eng VM, Schnyder B, LeHir M, Shakhov AN, Woerly G, Huang S, Aguet M, Anderson TD, and Ryffel B (1995). Role of interferon-gamma in interleukin 12-induced pathology in mice. Am J Pathol 147:1693-1707.

Casanova JL, Jouanguy E, Lamhamedi S, Blanche S, and Fischer A (1995). Immunological conditions of children with BCG disseminated infection. Lancet 346:581.

Chan J, Tanaka K, Carroll D, Flynn J, and Bloom BR (1995). Effects of nitric oxide synthase inhibitors on murine infection with Mycobacterium tuberculosis. Infect Immun 63:736-740.

Chan J, Xing Y, Magliozzo RS, and Bloom BR (1992). Killing of virulent Mycobacterium tuberculosis by reactive nitrogen intermediates produced by activated murine macrophages. $J$ Exp Med 175:1111-1122.

Cooper AM, Dalton DK, Stewart TA, Griffin JP, Russell DG, and Orme IM (1993). Disseminated tuberculosis in interferon gamma gene-disrupted mice. J Exp Med 178:2243-2247.

Cooper AM, Magram J, Ferrante J, and Orme IM (1997). Interleukin 12 (IL-12) is crucial to the development of protective immunity in mice intravenously infected with mycobacterium tuberculosis. J Exp Med 186:39-45.

Dalton DK, Pitts-Meek S, Keshav S, Figari IS, Bradley A, and Stewart TA (1993). Multiple defects of immune cell function in mice with disrupted interferon-gamma genes. Science 259: 1739-1742. 
de Jong R, Altare F, Haagen IA, Elferink DG, Boer T, van Breda Vriesman PJ, Kabel PJ, Draaisma JM, van Dissel JT, Kroon FP, Casanova JL, and Ottenhoff TH (1998). Severe mycobacterial and Salmonella infections in interleukin-12 receptor-deficient patients. Science 280:1435-1438.

Diefenbach A, Schindler H, Rollinghoff M, Yokoyama WM, and Bogdan C (1999). Requirement for type 2 NO synthase for IL-12 signaling in innate immunity. Science 284:951-955.

Doherty TM and Sher A (1997). Defects in cell-mediated immunity affect chronic, but not innate, resistance of mice to Mycobacterium avium infection. J Immunol 158:4822-4831.

Eigler A, Moeller J, and Endres S (1995). Exogenous and endogenous nitric oxide attenuates tumor necrosis factor synthesis in the murine macrophage cell line Raw 264.7. $\mathrm{J}$ Immunol 154:4048-4054.

Fang FC (1997). Perspectives series: Host/pathogen interactions. Mechanisms of nitric oxide-related antimicrobial activity. J Clin Invest 99:2818-2825.

Flick DA and Gifford GE (1984). Comparison of in vitro cell cytotoxic assays for tumor necrosis factor. Immunol Methods 68:167-175.

Flynn JL, Chan J, Triebold KJ, Dalton DK, Stewart TA, and Bloom BR (1993). An essential role for interferon gamma in resistance to Mycobacterium tuberculosis infection. J Exp Med 178:2249-2254.

Flynn JL, Goldstein MM, Chan J, Triebold KJ, Pfeffer K, Lowenstein CJ, Schreiber R, Mak TW, and Bloom BR (1995a). Tumor necrosis factor-alpha is required in the protective immune response against Mycobacterium tuberculosis in mice. Immunity 2:561-572.

Flynn JL, Goldstein MM, Triebold KJ, Sypek J, Wolf S, and Bloom BR (1995b). IL-12 increases resistance of BALB/C mice to Mycobacterium tuberculosis infection. $\mathrm{J}$ Immunol 155:2515-2524.

Flynn JL, Scanga CA, Tanaka KE, and Chan J (1998). Effects of aminoguanidine on latent murine tuberculosis. J Immunol 160:1796-1803.

Fowler AA, Fisher BJ, Sweeney LB, Wallace TJ, Natarajan R, Ghosh SS, and Ghosh S (1999). Nitric oxide regulates interleukin-8 gene expression in activated endothelium by inhibiting NF-kappaB binding to DNA: Effects on endothelial function. Biochem Cell Biol 77:201-208.

Garcia I, Miyazaki Y, Araki K, Araki M, Lucas R, Grau GE, Milon G, Belkaid Y, Montixi C, Lesslauer W, and Vassalli P (1995). Transgenic mice expressing high levels of soluble TNF-R1 fusion protein are protected from lethal septic shock and cerebral malaria, and are highly sensitive to Listeria monocytogenes and Leishmania major infections. Eur J Immunol 25:2401-2407.

Garcia I, Miyazaki Y, Marchal G, Lesslauer W, and Vassalli P (1997). High sensitivity of transgenic mice expressing soluble TNFR1 fusion protein to mycobacterial infections: Synergistic action of TNF and IFN-gamma in the differentiation of protective granulomas. Eur J Immunol 27:3182-3190.

Gomes MS, Florido M, Pais TF, and Appelberg R (1999). Improved clearance of Mycobacterium avium upon disruption of the inducible nitric oxide synthase gene. J Immunol 162:6734-6739.

Huang FP, Niedbala W, Wei XQ, Xu D, Feng GJ, Robinson JH, Lam C, and Liew FY (1998). Nitric oxide regulates Th1 cell development through the inhibition of IL-12 synthesis by macrophages. Eur J Immunol 28:4062-4070.

luvone T, D'Acquisto F, Carnuccio R, and Di Rosa M (1996). Nitric oxide inhibits LPS-induced tumor necrosis factor synthesis in vitro and in vivo. Life Sci 59:PL207-211.

Jouanguy E, Altare F, Lamhamedi S, Revy P, Emile JF, Newport M, Levin M, Blanche S, Seboun E, Fischer A, and Casanova JL (1996). Interferon-gamma-receptor deficiency in an infant with fatal bacille Calmette-Guerin infection. N Engl J Med 335:1956-1961.

Jouanguy E, Lamhamedi-Cherradi S, Altare F, Fondaneche MC, Tuerlinckx D, Blanche S, Emile JF, Gaillard JL, Schreiber R, Levin M, Fischer A, Hivroz C, and Casanova JL (1997). Partial interferon-gamma receptor 1 deficiency in a child with tuberculoid bacillus Calmette-Guerin infection and a sibling with clinical tuberculosis. J Clin Invest 100:2658-2664.

Jouanguy E, Lamhamedi-Cherradi S, Lammas D, Dorman SE, Fondaneche MC, Dupuis S, Doffinger R, Altare F, Girdlestone J, Emile JF, Ducoulombier H, Edgar D, Clarke J, Oxelius VA, Brai M, Novelli V, Heyne K, Fischer A, Holland SM, Kumararatne DS, Schreiber RD, and Casanova JL (1999). A human IFNGR1 small deletion hotspot associated with dominant susceptibility to mycobacterial infection. Nat Genet 21:370-378.

Kamijo R, Harada H, Matsuyama T, Bosland M, Gerecitano J, Shapiro D, Le J, Koh SI, Kimura T, Green SJ, Mak TW, Taniguchi T, and Vilcek J (1994). Requirement for transcription factor IRF-1 in NO synthase induction in macrophages. Science 263:1612-1615.

Kamijo R, Le J, Shapiro D, Havell EA, Huang S, Aguet M, Bosland M, and Vilcek J (1993). Mice that lack the interferongamma receptor have profoundly altered responses to infection with Bacillus Calmette-Guerin and subsequent challenge with lipopolysaccharide. J Exp Med 178:1435-1440.

Kindler V, Sappino AP, Grau GE, Piguet PF, and Vassalli P (1989). The inducing role of tumor necrosis factor in the development of bactericidal granulomas during BCG infection. Cell 56:731-740.

Kreuger MR, Tames DR, and Mariano M (1998). Expression of NO-synthase in cells of foreign-body and BCG-induced granulomata in mice: Influence of L-NAME on the evolution of the lesion. Immunology 95:278-282.

Lauw FN, Dekkers PE, te Velde AA, Speelman P, Levi M, Kurimoto M, Hack CE, van Deventer SJ, and van der Poll T (1999). Interleukin-12 induces sustained activation of multiple host inflammatory mediator systems in chimpanzees. J Infect Dis 179:646-652.

Lucas R, Tacchini-Cottier F, Guler R, Vesin D, Jemelin S, Olleros ML, Marchal G, Browning JL, Vassalli P, and Garcia I (1999). A role for lymphotoxin $\beta$ receptor in host defense against Mycobacterium bovis BCG infection. Eur $\mathrm{J}$ Immunol 29:4002-4010.

MacMicking JD, Nathan C, Hom G, Chartrain N, Fletcher DS, Trumbauer M, Stevens K, Xie QW, Sokol K, Hutchinson N, Chen H, and Mudgett JS (1995). Altered responses to bacterial infection and endotoxic shock in mice lacking inducible nitric oxide synthase. Cell 81:641-650.

MacMicking JD, North RJ, LaCourse R, Mudgett JS, Shah SK, and Nathan CF (1997). Identification of nitric oxide synthase as a protective locus against tuberculosis. Proc Natl Acad Sci U S A 94:5243-5248. 
Madge LA, Sierra-Honigmann MR, and Pober JS (1999). Apoptosis-inducing agents cause rapid shedding of tumor necrosis factor receptor 1 (TNFR1). A nonpharmacological explanation for inhibition of TNF-mediated activation. J Biol Chem 274:13643-13649.

Peng HB, Rajavashisth TB, Libby P, and Liao JK (1995). Nitric oxide inhibits macrophage-colony stimulating factor gene transcription in vascular endothelial cells. J Biol Chem 270: 17050-17055.

Raychaudhuri B, Dweik R, Connors MJ, Buhrow L, Malur A, Drazba J, Arroliga AC, Erzurum SC, Kavuru MS, and Thomassen MJ (1999). Nitric oxide blocks nuclear factor-kappaB activation in alveolar macrophages. Am J Respir Cell Mol Biol 21:311-316.

Rothe H, Hartmann B, Geerlings P, and Kolb H (1996). Interleukin-12 gene-expression of macrophages is regulated by nitric oxide. Biochem Biophys Res Commun 224:159163.

Shiloh MU, MacMicking JD, Nicholson S, Brause JE, Potter S, Marino M, Fang F, Dinauer M, and Nathan C (1999). Phenotype of mice and macrophages deficient in both phagocyte oxidase and inducible nitric oxide synthase. Immunity 10:29-38.

Shiratsuchi H, Johnson JL, and Ellner JJ (1994). Mycobacterium avium: Pathogenicity in HIV1 infection. Res Microbiol 145:230-236.

Sugawara I, Yamada H, Kaneko H, Mizuno S, Takeda K, and Akira S (1999). Role of interleukin-18 (IL-18) in mycobacterial infection in IL-18-gene-disrupted mice. Infect Immun 67: 2585-2589.
Thomassen MJ, Buhrow LT, Connors MJ, Kaneko FT, Erzurum SC, and Kavuru MS (1997). Nitric oxide inhibits inflammatory cytokine production by human alveolar macrophages. Am J Respir Cell Mol Biol 17:279-283.

Truyens C, Torrico F, Lucas R, De Baetselier P, Buurman WA, and Carlier $Y$ (1999). The endogenous balance of soluble tumor necrosis factor receptors and tumor necrosis factor modulates cachexia and mortality in mice acutely infected with Trypanosoma cruzi. Infect Immun 67:5579-5586.

Wakeham J, Wang J, Magram J, Croitoru K, Harkness R, Dunn P, Zganiacz A, and Xing Z (1998). Lack of both types 1 and 2 cytokines, tissue inflammatory responses, and immune protection during pulmonary infection by Mycobacterium bovis bacille Calmette-Guerin in IL-12-deficient mice. J Immunol 160:6101-6111.

Walley KR, McDonald TE, Higashimoto Y, and Hayashi S (1999). Modulation of proinflammatory cytokines by nitric oxide in murine acute lung injury. Am J Respir Crit Care Med 160:698-704.

Yoshida A, Koide Y, Uchijima M, and Yoshida TO (1995). Dissection of strain difference in acquired protective immunity against Mycobacterium bovis Calmette-Guerin bacillus (BCG). Macrophages regulate the susceptibility through cytokine network and the induction of nitric oxide synthase. J Immunol 155:2057-2066. 